\title{
Sıcak Basması İnanç Ölçeği’nin Geçerlilik ve Güvenilirlik Çalışması*
}

\author{
Validity and Reliability of the Hot Flush Beliefs Scale's Turkish Version
}

\author{
Aslı SİS ÇELİK ${ }^{\mathrm{a}}$ Türkan PASİNLİOĞLU ${ }^{\mathrm{b}}$
}

\begin{abstract}
ÖZET Amaç: Bu çalışma Sıcak Basması İnanç Ölçeğinin (SBïÖ), Türkçeye uyarlanarak geçerlik ve güvenirliğinin test edilmesi amacıyla yapılmıştır. Gereç ve Yöntem: Metodolojik türde yapılan araştırmanın örneklemini bir Aile Sağlığı Merkezine başvuran kadınlar arasından olasılıksız rastlantısal örnekleme yöntemi ile seçilen, en az bir aydır sıcak basması şikâyeti yaşayan ve araştırmaya katılmayı kabul eden 247 kadın oluşturmuştur. Araştırmanın verileri "Kişisel Bilgi Formu" ve "Sıcak Basması İnanç Ölçeğinin Türkçe formu" kullanılarak ve kadınlarla yüz yüze görüşülerek toplanmıştır. Veriler SPSS 20 programı ve LİSREL 9.1 programında değerlendirilmiştir. Ölçeğin çeviri sürecinin ardından geçerliliğine yönelik kapsam ve yapı geçerliliği yapılmıştır. Kapsam geçerliliği için uzman görüşleri sonrası kapsam geçerlilik indeksi hesaplanmıştır. Yapı geçerliliği için açımlayıcı faktör analizi ve doğrulayıcı faktör analizi, güvenirlik için madde analizleri ve iç tutarlık analizi yapılmıştır. Bulgular: Ölçeğin açımlayıcı faktör analizi sonucunda 3 faktörlü bir yapı gösterdiği ve faktör yüklerinin uygun aralıkta olduğu saptanmıştır (0.77-0.40). Doğrulayıcı faktör analizi sonucunda ise ölçeğin 3 faktörlü yapısının geçerli olduğu ve model-veri uyumunun kabul edilebilir düzeyde olduğu belirlenmiștir. Ölçeğin Cronbach's alfa katsayısının 0.90, alt boyutlarının Cronbach's alfa katsayısının ise 0.760.88 arasında olduğu bulunmuștur. Ölçeğin zamana göre değiş̧mezliğini test etmek için 122 kadına ilk uygulamadan iki hafta sonra ölçek tekrar uygulanmış, test-tekrar test korelasyon değeri 0.90 olarak bulunmuş ve iki uygulama arasında istatistiksel açıdan anlamlı bir ilişki olduğu saptanmıştır $(p=0.000)$. Ölçeğin iç tutarlılık analizlerinde, madde toplam puan korelasyonları incelenmiş, 0.30 ile 0.69 arasında olduğu belirlenmiş ve ölçekten herhangi bir madde çıkarılmamıștır. Sonuçlar: SBİÖ'nün Türkçe formunun kadınların sıcak basmasına iliş̧in inançlarını değerlendirmede geçerli ve güvenilir bir ölçme aracı olduğu saptanmıştır.
\end{abstract}

Anahtar Kelimeler: Geçerlilik ve güvenilirlik, Sıcak basması, Sıcak basması inanç ölçeği

\begin{abstract}
Aim: The aim of this study was to adapt the Hot Flush Beliefs Scale (HFBS) into Turkish and test its validity and reliability. Method: The sample group of this methodological study consisted of 247 women who were selected with nonprobability random sampling method among women applying to a Family Health Center, had hot flush complaint for at least one month and accepted to participate in the study. Data of the study were collected by using "Personal Information Form" and "Turkish Version of Hot Flush Beliefs Scale". HFBS was performed with face-to-face interview. The data were analysed in SPSS 20 pocket programme and LISREL 9.1. After the translation to Turkish of the scale, content and construct validity were made. The content validity index was calculated after experts' views for content validity. Exploratory factor analysis and confirmatory factor analysis were used for construct validity and the internal consistency and item analysis were used for reliability. Results: As a result of the explanatory factor analysis, it was determined that the scale showed a three-factor structure and factor loadings were within proper range (0.77-0.40). On the other hand, as a result of the confirmatory factor analysis, it was found out that three-factor structure of the scale was valid and modeldata fit was at acceptable level. While Cronbach's alpha coefficient of the scale was 0.90, Cronbach's alpha coefficient of its subscales was between 0.76-0.88. In order to test invariance of the scale by time, the scale was performed to 122 women again two weeks after the first application, and it was found out that the test-retest correlation value was 0.90 and there was a statistical significant relation between two applications $(p=0.000)$. In internal consistency analysis of the scale, it was determined that item total score correlations were between 0.30 and 0.69 and no item was excluded from the scale. Conclusion: It was determined that Turkish version of HFBS is a valid and reliable assessment instrument to evaluate beliefs of women regarding the hot flush.
\end{abstract}

Key words: Validity and reliability, hot flush, hot flush beliefs scale

Geliş Tarihi/Recevied: 31.10.2014 Kabul Tarihi/Accepted:01.03.2015

*Bu çalışma 2013 yılında Atatürk Üniversitesi Sağlık Bilimleri Enstitüsü tarafindan kabul edilen Doktora Tezinden hazırlanmıştır.

${ }^{a}$ Yrd. Doç. Dr. Atatürk Üniversitesi Sağlık Bilimleri Fakültesi, Hemşirelik Bölümü, Kampus/ Erzurum e-mail: aslisis@ @otmail.com / aslisis@ atauni.edu.tr Tlf: + (90) 4422312689

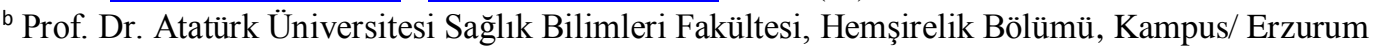

e-mail: tpasin@ atauni.edu.tr, Tlf: + (90) 4422311233 


\section{Giriş}

Menopozal dönemde kadında; östrojen eksikliğine bağlı fiziksel ve ruhsal birtakım değişiklikler meydana gelmekte ve kadının yaşamı olumsuz yönde etkilenmektedir. Yapılan çalışma sonuçlarına göre menopoz dönemindeki kadınlar arasında en yaygın görülen ve en çok şikâyetçi olunan sorunun vazomotor semptomlar olduğu belirlenmiştir. ${ }^{1-4}$ Mekanizması tam olarak aydınlatılmamış olan vazomotor değişikliklerin belirtileri genellikle "yüz kızarması", "ateş basması", "gece terlemesi" şeklinde görülmektedir. Bu üç belirtinin hepsine birden, "sıcak basması" denilmektedir. ${ }^{5}$ Sicak basması menopoz döneminin karakteristik bir semptomu olup, görülme sıklı̆g $\%$ 60-85 arasında değişmektedir. ${ }^{6}$ Sicak basmaları göğsün üst kısmından başlayarak boyuna ve başa doğru yayılır, buna kızarma da eşlik eder; ardından terleme ve üşüme görülebilir. Semptomlar sirasinda arteriyel kan basıncında değişiklik görülmez. $\mathrm{Bu}$ belirtiler birkaç saniyeden birkaç saate kadar sürebilir. $\mathrm{Bu}$ subjektif yakınmaları her kadın farklı şiddette yaşar, farklı şekilde algılar ve bu doğrultuda başa çıkma mekanizması geliştirir. Hunter ve Liao $^{7}$ yaptıkları çalışmada, sıcak basması yaşayan kadınların düşünceleriyle bağlantılı olarak çeşitli duygusal tepkiler bildirdiklerini belirtmişlerdir. İlgili çalışmada; sıcak basması esnasında sosyal bağlamda yaşanan endişeler ("birileri beni görebilir mi?") sosyal kaygı ve utanç hislerine yol açmış; başa çıkma ve kontrol edilebilirlikle ilgili bilişsel tepkiler ise ("bu bir gün bitecek mi?") can sıkıntısı veya çaresizlikle sonuçlanmıştır. Bunun aksine, sıcak basması esnasında sakin ya da baş edebilen düşünceler bildiren kadınlar ise ("bu durum geçecek") daha az duygusal sıkıntı yaşamışlardır. ${ }^{7}$

Klimakterium dönemindeki kadının fiziksel, ruhsal ve sosyal yaşantısının tam bir iyilik halinde olabilmesi için, bu dönemde ortaya çıkabilecek sağlık sorunlarını bilmesi, önlem alması veya bunlarla baş etmeyi öğrenmesi gerekmektedir. Bunun için de desteğe, bilgiye ve danışmanlığa ihtiyaç duymaktadır. Hemşirenin, menopoz bakımındaki genel hedefleri; kadının ve ailesinin menopozal dönemi yaşamın doğal bir evresi olarak algılayabilmesini, bu döneme yönelik yanlış inanç ve algılamaların düzeltilmesini, fiziksel, emosyonel ve sosyal sorunlarla başa çıkabilmesini sağlamaktır.

Kadınların menopozal döneme yönelik inanç ve tutumlarını belirlemek için yapılan çalışmalarda menopoza ilişkin tutum ölçeğinin kullanıldığ 1 görülmüştür. Ancak ilgili ölçek menopoz döneminde yaşanan yakınmalara yönelik tutumlar hakkında ayrı ayrı bilgi vermemektedir. $\mathrm{Bu}$ nedenle menopozal dönemde en yaygın görülen ve en çok şikayetçi olunan vazomotor semptomlara yönelik kadınların inanç ve tutumlarını belirlemek için kullanılacak bir ölçme aracına gereksinim vardır. Bu çalışma Sıcak Basması İnanç Ölçeği (SBİÖ)'nin Türkçeye uyarlayarak geçerlik ve güvenirliğinin değerlendirilmesi amacıyla yapılmıştır.

\section{Gereç ve Yöntem}

\section{Araştırmanın türü}

Araştırma, Sıcak Basması İnanç Ölçeği’ni Türkçeye uyarlayarak geçerlik ve güvenirliğini test etmek amaciyla metodolojik olarak yapılmıştır.

\section{Evren ve Örneklem}

Araştırmanın evrenini, 1 Aralık 2012 - 30 Ocak 2013 tarihleri arasında Erzurum il merkezinde bir Aile Sağllğ $\breve{1}_{1}$ Merkezi (ASM)'ne başvuran kadınlar oluşturmuştur.

Bir ölçeğin başka bir kültüre uyarlanmasında ve likert tipi ölçekten anlamlı ve güvenilir sonuçların alınabilmesi için ölçek madde sayısının en az 5-10 katı büyüklüğünde bir gruba ulaşılması gerekmektedir. ${ }^{8,9} \mathrm{Bu}$ nedenle, yukarıda belirtilen evrenden olasiliksız rastlantısal örnekleme yöntemi ile seçilen, en az bir aydır sıcak basması şikâyeti yaşayan ve araştırmaya katılmayı kabul 
eden 247 kadın araştırmanın örneklemini oluşturmuştur.

\section{Verilerin Toplanması}

Araştırmanın verileri Kişisel Bilgi Formu ve SBİÖ Türkçe formu kullanılarak araştırmacı tarafından ilgili ASM'ye başvuran kadınlarla yüz yüze görüşme yöntemi ile toplanmıştır.

Kişisel Bilgi $\begin{gathered}\text { Formu: Araştırmacı } \\ \text { tarafından, }\end{gathered}$ literatür bilgileri $i^{1-3,10}$
doğrultusunda
hazırlanan form 16 soru
eğitim düzeyi, aile tipi, gelir durumu gibi
tanıtıcı bilgilerini ve menopozal
özelliklerini belirleyen sorular yer
almaktadır.

Sıcak Basmast Inanç Ölçeği (The Hot Flush Beliefs Scale:HFBS): Ölçek, Rendall ve ark. tarafından kadınların sıcak basmasına ilişkin inançlarını ölçmek amacıyla 2008 yılında geliştirilmiştir. ${ }^{11}$ Ölçek 27 maddeden ve üç alt boyuttan oluşmaktadır.

- Sosyal bağlamda kendi hakkındaki inançları alt boyutu (beliefs about self in social context): Kadınların sosyal ortamlarda sıcak basması yaşadıkları zaman hissettiklerini tanımlayan 13 maddeden (1, 6-11, 13, 14, 17, 20, 21, 23) oluşmaktadır.

- Sicak basmasi ile başa çıkma konusundaki inançlar alt boyutu (beliefs about coping with hot flushes): Kadınların sicak basması sorunu ile başa çıkma konusundaki inançlarını tanımlayan 10 maddeden $(2,5,12,15$, $16,18,19,24,26,27)$ oluşmaktadır.

- Gece terlemeleri ile başa çıkma konusundaki inançlar alt boyutu (Beliefs about Coping with Night Sweats/Sleep): Kadınların gece terlemesi sorunu ile başa çıkma konusundaki inançlarını tanımlayan 4 maddeden $(3,4,22,25)$ oluşmaktadır.

Orijinal ölçeğin her bir maddesi "kesinlikle katılmıyorum" (0 puan) ile "kesinlikle katıliyorum" (5 puan) arasında değişen 6'l likert tipi şeklinde derecelendirilmiştir. 2, 4, 5,11, 15, 18, 25 nolu maddeler ters kodlanmaktadır. Ölçek maddeleri 0-5 puan arasinda puanlanmaktadır. Ölçeğin toplam punı 0135 arasında değişmekte olup, düşük puan olumsuz inancı göstermektedir.

Rendall ve ark. tarafindan yap1 geçerliliği için yapılan faktör analizi sonucunda, ölçeğin 3 alt boyuttan oluştuğu, her bir alt boyutun Cronbach alfa değerlerinin 0.78-0.93 arasında olduğu, ölçeğin toplam Cronbach alfa değerlerinin 0.94 olduğu; madde toplam puan korelasyon katsayılarının $r=0.22$ ile $r=0.70$ arasında olduğu, test-re-test korelasyon değerinin $r=0.72$ olduğu bulunmuştur. ${ }^{11}$

\section{Araştırmanın Etiği}

Sıcak Basması İnanç Ölçeği'nin Türkçeye uyarlanması için ölçeğin geliştirilmesi çalışmasının araştırmacılarından biri olan Myra S. Hunter ile e-posta ile iletişim kurularak yazılı izin alınmıştır. Araştırmanın yapılabilmesi için Atatürk Üniversitesi Sağlık Bilimleri Enstitüsü Etik Kurulu'ndan onay alınmıştır. Araştırmanın ilgili Aile Sağlığı Merkezinde yürütülmesi için Erzurum Halk Sağlık Müdürlüğü'nden yazılı izin alınmıştır.

Araştırma kapsamındaki kadınların haklarının korunması için araştırma verilerini toplamaya başlamadan önce kadınlara, araştırmanın yapılma amacı açıklanarak "Aydınlatılmış Onam” ilkesi, elde edilen bilgilerin gizli tutulacağ belirtilerek "Gizlilik ve Gizliliğin Korunması" ilkesi, araştırmaya gönüllü olarak katılmak isteyenlerin alınması ile de "Özerkliğe Saygı" ilkesini içeren etik ilkeler yerine getirilmiştir.

\section{Bulgular ve Tartışma Dil Geçerliliği}

SBİÖ'nün dil geçerliği için geri çeviri yöntemi kullanılmıştır. ${ }^{12}$ SBİÖ İngilizceye hakim, birisi mütercim olmak üzere iki uzman ve üç öğretim üyesi tarafindan İngilizceden Türkçeye çevrilmiştir. Türkçeye çevrilen tüm formlar araştırmac1 tarafindan tekrar gözden geçirilerek tek form haline getirilmiştir. Daha sonra 
Türkçeye çevrilen formun her iki dili iyi bilen bir İngilizce dil bilim uzmanı tarafindan geri çevirisi yapılmıştır. Orjinal ölçek ile Türkçeye çevrilen şekli karşılaştırılmış ölçeğin ifadelerinde anlam değişikliği olmadığı belirlenmiştir. Son olarak ölçeğin Türkçesi Türk Dili Edebiyatı bölümünden bir Türk Dili uzmanı tarafindan kontrol edilmiştir. Öneriler doğrultusunda daha anlaşılır hale getirilen ölçeğe son şekli verilmiş ve içerik geçerliliği için uzman görüşüne sunulmuştur. ${ }^{9}$

\section{İçerik Geçerliliği}

Ölçeğin İngilizce ve Türkçe formu 8 kişilik uzman görüşüne sunulmuştur. Uzman değerlendirmesi için içerik geçerlilik indeksi (Content Validity Index-CVI) kullanılmıştır. ${ }^{13}$ Uzman kişilerden ölçekteki her bir ifadeyi 4: "Çok uygun", 3: "Oldukça uygun", 2: "Cümle düzeltilirse uygun olur", 1: "Uygun değil”" şeklindeki ifadeleri kullanarak, her maddenin 1-4 puan arasında değerlendirmeleri istenmiştir. Değerlendirme sonucunda uzman kişilerin çok uygun dediği ifadeler aynen kabul edilirken düzeltme istedikleri ya da uygun bulmadikları ifadeler tekrar gözden geçirilerek düzeltilmiştir. Uzman görüşüne göre her bir maddenin kabul edilebilir puan ortalamasinın 3 puanın üzerinde olduğu ve $\% 95$ oranında 3 ve 4 puan olarak değerlendirdikleri belirlenmiştir. Ön uygulama yapılan grupta ölçekteki ifadelerin anlaşılır olduğu gözlenmiştir. Uzmanların önerileri ve ön uygulama sonucunda ölçek son halini almıştır. Uzman görüşleri sonucunda SBİÖ’nün Türkçe formunun dil ve içerik yönünden uygun bir ölçüm aracı olduğu söylenebilir.

\section{İç Tutarlılık}

Toplam 247 kadın üzerinde uygulanan ölçeğin Türkçe formunun iç tutarlılık denetiminde madde toplam puan korelasyonlar1, Cronbach alfa değerlendirmesi ve faktör analizi kullanılmıştır. ${ }^{14,15}$

Her bir madde puanı ile toplam madde puanı arasındaki ilişkiyi ve ölçeği oluşturan her bir maddenin eşit ağırlıkta olup olmadığını değerlendirmek için yapilan madde toplam puan (madde birakma) korelasyonunun 0.30 ile 0.69 arasında olduğu bulunmuştur (Tablo 1). Ölçeğin toplanabilirlik özelliğinin bozulmaması için madde toplam puan korelasyonlarının hangi ölçütün altına düşünce güvenilirliğinin yetersiz sayılacağ 1 konusunda belirli bir standart olmamakla birlikte Akgül'e göre 0.25 ten büyük olması gerekir. ${ }^{12}$

\section{Cronbach Alfa Güvenirlik Katsayı Analizi}

Cronbach alfa katsayısı ölçek içindeki maddelerin iç tutarlılığının ve homojenliğinin bir göstergesidir. Ölçeğin alfa katsayısı ne kadar yüksek olursa ölçekte bulunan maddelerin o ölçüde birbiriyle tutarlı olduğunu ve aynı özelliği ölçen maddelerden oluştuğunu gösterir. Likert tipi bir ölçekte yeterli sayılabilecek güvenirlik katsayısı olabildiğince 1'e yakın olmalıdır. $^{12,15} \mathrm{Bu}$ araştırmada Sicak Basması İnanç Ölçeğinin Cronbach alfa güvenirlik katsayısı 0.90 olarak bulunmuştur. Rendall ve ark. çalışmasında da Cronbach alfa güvenirlik katsayısı 0.94'dür. ${ }^{11} \mathrm{Bu}$ bulgu, ölçeğin iç tutarlılığa sahip çok yüksek derecede güvenilir bir ölçek olduğunu göstermektedir.

\section{Yapı Geçerliliği}

SBİÖ’nün faktör yapısı incelenmeden önce örneklemin faktör analizi için yeterli olup olmadığını değerlendirmek amacıyla Kaiser-Meyer-Olkin (KMO) ve örneklemin faktör analizi için uygun olup olmadığını değerlendirmek için Bartlett's Test of Sphericity (BTS) analizleri uygulanmıştır. 
Tablo 1. Sıcak Basması İnanç Ölçeğinin Madde Analizi Sonuçları

\begin{tabular}{|c|c|c|c|}
\hline Ölçek Maddeleri & $\begin{array}{c}\text { Madde } \\
\text { ortalaması }\end{array}$ & $\begin{array}{c}\text { Madde } \\
\text { toplam puan } \\
\text { korelasyonu }\end{array}$ & $\begin{array}{c}\text { Madde } \\
\text { silindiğinde } \\
\text { ölçek alfası }\end{array}$ \\
\hline $\begin{array}{l}\text { 1. Sıcak basması yaşadığım zaman, etrafımdaki insanlar } \\
\text { bana bakıyormuş gibi geliyor }\end{array}$ & 1.85 & .54 & .90 \\
\hline $\begin{array}{l}\text { 2. Sıcak basmalarının verdiği fiziksel rahatsızlık ile başa } \\
\text { çıkabilirim }\end{array}$ & 2.04 & .41 & .90 \\
\hline $\begin{array}{l}\text { 3. Gece terlemesi ile uyandığım zaman, tekrar uykuya } \\
\text { geçmekte zorlanırım }\end{array}$ & 2.55 & .31 & .90 \\
\hline $\begin{array}{l}\text { 4. Gece terlemesi nedeni ile uykum bölünse de } \\
\text { ertesi gün normal hayatıma devam edebilirim }\end{array}$ & 1.75 & .30 & .90 \\
\hline $\begin{array}{l}\text { 5. Sicak basmalarının yaşamımı olumsuz etkilemesine } \\
\text { izin vermem }\end{array}$ & 1.86 & .42 & .90 \\
\hline $\begin{array}{l}\text { 6. İnsanların yanında sıcak basması yaşadığım } \\
\text { zaman huzursuz oluyorum }\end{array}$ & 3.02 & .50 & .90 \\
\hline 7. Sıcak basması yaşadığım zaman utanıyorum & 1.51 & .64 & .90 \\
\hline $\begin{array}{l}\text { 8. S1cak basması yaşadığım zaman, nasıl göründüğüm } \\
\text { konusunda endişeleniyorum }\end{array}$ & 1.88 & .64 & .90 \\
\hline 9. Sicak basmaları, kendimi itici hissetmeme neden oluyor & 1.57 & .69 & .90 \\
\hline $\begin{array}{l}\text { 10. Sıcak basması yaşadığım zaman, diğer insanlar benim } \\
\text { beceriksiz olduğumu düşüneceklermiş gibi hissediyorum }\end{array}$ & .85 & .54 & .90 \\
\hline $\begin{array}{l}\text { 11. Sıcak basması yaşadığım zaman, diğer insanların bu } \\
\text { konuda ne düşündügünü umursamam }\end{array}$ & 1.73 & .37 & .90 \\
\hline $\begin{array}{l}\text { 12. Sıcak basmalarım nedeniyle kendimi boğulacakmış gibi } \\
\text { hissediyorum }\end{array}$ & 3.56 & .38 & .90 \\
\hline $\begin{array}{l}\text { 13. Sıcak basması yaşadığım zaman, sanki insanlar benim } \\
\text { bir sıkıntım olduğunu düşüneceklermiş gibi geliyor }\end{array}$ & 1.81 & .59 & .90 \\
\hline $\begin{array}{l}\text { 14. Sicak basması yaşadığımda yapılacak en iyi şey, } \\
\text { sosyal ortamlardan uzak durmaktır }\end{array}$ & 1.93 & .54 & .90 \\
\hline $\begin{array}{l}\text { 15. Sıcak basması yaşadığım zaman, bunu görmezden } \\
\text { gelebilirim }\end{array}$ & 2.31 & .45 & .90 \\
\hline $\begin{array}{l}\text { 16. Diğer insanların sıcak basmalarıyla benden } \\
\text { daha iyi baș edebildiklerini düșünüyorum }\end{array}$ & 1.51 & .33 & .90 \\
\hline $\begin{array}{l}\text { 17. Sıcak basması yaşadığım zaman, başkalarının } \\
\text { gözünde aptal gibi göründügüümü düşünüyorum }\end{array}$ & .65 & .44 & .90 \\
\hline 18. Sıcak basmalarımla etkili bir şekilde baş edebilirim & 1.92 & .52 & .90 \\
\hline $\begin{array}{l}\text { 19. Sıcak basmaları nedeniyle kendimi gücenmiş } \\
\text { (kırgın) hissediyorum }\end{array}$ & 2.56 & .49 & .90 \\
\hline $\begin{array}{l}\text { 20. Sıcak basması yaşadığımda, kendimi işe } \\
\text { yaramaz hissediyorum }\end{array}$ & 1.29 & .58 & .90 \\
\hline $\begin{array}{l}\text { 21. Sicak basmaları, diğer insanların hakkımda ne } \\
\text { düşündüğüne daha çok önem vermeme neden } \\
\text { oluyor }\end{array}$ & 1.11 & .55 & .90 \\
\hline $\begin{array}{l}\text { 22. Gece terlemesi yaşadığım zaman, ertesi gün } \\
\text { işlerimi yapmak daha zor oluyor }\end{array}$ & 1.77 & .51 & .90 \\
\hline $\begin{array}{l}\text { 23. Sıcak basması yaşadığım zaman, dikkatleri } \\
\text { üzerime çektiğimi hissediyorum }\end{array}$ & 1.98 & .61 & .90 \\
\hline $\begin{array}{l}\text { 24. Acaba bir sonraki sıcak basması ne zaman } \\
\text { olacak diye endişeleniyorum }\end{array}$ & 2.47 & .59 & .90 \\
\hline 25. Gece terlemeleri, genel sağlığımı etkilemiyor & 2.50 & .37 & .90 \\
\hline $\begin{array}{l}\text { 26. S1cak basması yaşadığım zaman kendimi } \\
\text { huzursuz hissediyorum }\end{array}$ & 3.52 & .49 & .90 \\
\hline $\begin{array}{l}\text { 27. Sıcak basması yaşadığımda, bunlar ne zaman } \\
\text { sona erecek diye düşünüyorum }\end{array}$ & 3.65 & .45 & .90 \\
\hline
\end{tabular}


Tablo 2. Kaiser-Meyer-Olkin (KMO) ve Barlett's Test Sonuçları

\begin{tabular}{lcc}
\hline Testler $(\mathrm{N}=247)$ & Sonuçlar & $\mathbf{p}$ \\
\hline KMO & 0.90 & \\
Bartlett's Test & $\mathrm{X}^{2}=2565.339$ & $\mathrm{p}=0.000$ \\
\hline
\end{tabular}

Ölçeğin KMO ile hesaplanan örneklem yeterliliği 0.90 olarak saptanmıştır. Literatür iyi bir KMO değerinin 0.70 ve üzerinde olması gerektiğini vurgulamaktadır. ${ }^{12,15} \mathrm{Bu}$ değer ölçeğin örneklem büyüklüğünün çok iyi olduğunu göstermektedir. Barlett's Test sonucunda ise $\mathrm{X}^{2}=2565.339$ olarak bulunmuş ve $\mathrm{p}<0.001$ önem düzeyinde anlamlı olduğu görülmüştür (Tablo 2). Bu bulgu ölçeğin faktör analizi için uygun olduğunu göstermektedir.

\section{Ölçeğin Zamana Karşı Değişmezliği (Test- Tekrar Test)}

Tablo 3. Test-Tekrar-Test Puanlarının Korelasyon Analizi

\begin{tabular}{lccc}
\hline $\begin{array}{l}\text { SBİÖ’nün Test-Tekrar-Test } \\
\text { Uygulaması }\end{array}$ & $\mathbf{X} \pm \mathbf{S S}$ & $\mathbf{r}$ & $\mathbf{p}$ \\
\hline $\begin{array}{l}\text { Birinci uygulama } \\
\text { İkinci uygulama }\end{array}$ & $55.29 \pm 28.73$ & & \\
\hline
\end{tabular}

SBİÖ’nin güvenilirliğini belirlemek için yapılan bir diğer analiz ise test-tekrar test uygulamasıdır. Bu uygulama ölçümün zamana karşı değişmezliğini ortaya çıkarır. İki ölçüm arasındaki korelasyon katsayısının yüksekliği ölçümün değişmezliğinin göstergesidir. ${ }^{15}$ Test-tekrar test 122 kişilik örneklem grubuna 2 hafta arayla uygulanmış ve test-tekrar test korelasyon katsayısı 0.90 olarak bulunmuştur (Tablo 3). Test-tekrar test sonucunda iki uygulama arasinda istatistiksel açıdan ileri derecede anlamlı

\section{Açımlayıcı Faktör Analizi}

Faktör analizi çok sayıda değişkeni daha küçük sayıdaki kategorilere veya faktörlere dönüştürmektedir. Yani çok sayıdaki değişken arasındaki birkaç değişken altında tanımlamaktadır. Bir başka ifade ile değişkenler kümesindeki içsel ilişkileri bir ilişki olduğu saptanmıştır $(\mathrm{p}<0.001)$. Rendall ve ark. geliştirdikleri orjinal ölçeğin test tekrar test korelasyon katsayısını 0.72 olarak bulmuşlardır. ${ }^{11} \mathrm{Bu}$ bulgu da ölçeğin orjinalinin test-tekrar test korelasyonunun anlamlı olduğunu göstermektedir. Araştırmada SBİÖ'nin test-tekrar test korelasyonunun 0.90 olarak bulunması ölçeğin yinelemeli ölçümlerde benzer ölçüm değerlerini sağlama özelliğine sahip, oldukça tutarlı bir ölçek olduğunu göstermektedir.

incelemeyi amaçlayan çok değişkenli çözümleme türüdür. Faktör analizi modelinin tahmininde en önemli adım, faktörlerin sayısının bulunmasıdır. SBİÖ'nün faktör yapısını belirlemek için "Principal Component" (temel bileşenler) yöntemi kullanılmış ve "Varimax" 
dönüştürmesine göre analizler yapılmıştır. Faktör yüklerinde çok anlamlı değişimler olmadığ 1 için, ayrıca açıklanacak varyansın 1 'e denk gelmesini yeni değişkenlerin bir şekilde bir araya toplanıp toplanmadığını incelemek amacı ile araştırmada bu yöntem tercih edilmiştir. ${ }^{14,16}$ Araştırmada ölçeğin maddelerinin üç faktör altında toplanmış olduğu bulunmuştur.

$\begin{array}{clr}\text { SBİÖnün faktöryel } & \text { yapısını } \\ \text { belirlemek için } & \text { yapılan } & \text { "Principal }\end{array}$ Component" (temel bileşenler) analizi sonucu maddelerin ve faktörlerin "toplam varyansı açıklama" oranları ve varimax dönüştürmesi uygulanması sonucu ortaya çıkan faktör yükleri ile ilgili bulgular Tablo 4.'te verilmiştir. Tablo 4. incelendiğinde SBİÖ'nün toplam varyans1 \%46.01 olarak bulunmuş ve maddelerin faktör yükleri 0.40 'dan 0.77 'ye kadar değişen bir dağılım göstermiştir. Rendall ve ark. çalışmasında da toplam varyans \%48.78 olup faktör analizi sonucu faktör dağılımının 0.53-0.80 arasında olduğu bulunmuştur. ${ }^{11}$ Araştırmada açıklanan varyans değerinin \%30'dan yüksek ve iç tutarlılık katsayısının da oldukça iyi bir düzeyde olması ölçeğin kullanılabilirliğini desteklemektedir. SBIOÖ'nün faktör analizi ile elde edilen bulgulara göre; Türkçeye uyarlaması yapılan SBİÖ'nün tutarlı ve kullanılabilir olduğu savunulabilir.

Yapılan açımlayıcı faktör analizi sonrası ölçekteki 1, 4, 7, 8, 9, 10, 12, 13, 14, 17, $19,20,21,22,23,24,25,26,27$. maddeler orjinal ölçekte temsil ettikleri alt boyutlar içinde yer alırken, orjinal ölçekte faktöre 1'e ait olan 6. madde faktör 2 içinde, 11.madde faktör 3 içinde yer almıştır. Faktör 2'ye ait olan 2, 5, 15 ve 18. maddeler faktör 3 içinde, 16. madde faktör 1 içinde yer almıştır. Faktör 3' e ait olan 3.madde ise faktör 2 içinde yer almıştır. İlgili maddelerin faktörler arası yer değiştirmesi sonucu orijinal ölçeğin "sosyal bağlamda kendisi hakkındaki inançlart (Sosyal Algl)" alt boyutu ismi aynı kalmış orijinal ölçeğin "sıcak basması ile başa çıkma konusundaki inançları" alt boyutu ile "gece terlemesi ile başa çıkma konusundaki inançları" alt boyutu birleşerek "slcak basmasl ve gece terlemesi ile başa çıkma konusundaki inançları (Başetme Algisl)" adını almış ve ölçeğin üçüncü alt boyutunu oluşturmuştur. İkinci alt boyuta ise ilgili faktörde yer alan maddelerin anlamlarına uygun olarak "psikolojik bağlamda kendisi hakkındaki inançları (Psikolojik algı)" adı verilmiştir (Tablo 4).

\section{Doğrulayıcı Faktör Analizi}

Ölçeğin özgün formunun faktör yapısının Türk örneklemde doğrulanıp doğrulanmayacağını belirlemek üzere birinci ve ikinci düzey doğrulayıcı faktör analizi (DFA) yapılmıştır. DFA özellikle başka kültürlerde ve örneklemlerde geliştirilmiş ölçme araçlarının uyarlanmasında kullanılan bir geçerlilik belirleme yöntemidir. Sümer'e göre DFA kuramsal bir temelden destek alarak pek çok değişkenden oluşturulan faktörlerin gerçek verilerle ne derece uyum gösterdiğini değerlendirmeye yönelik bir analizdir. ${ }^{17}$ Bir başka anlatımla DFA, önceden belirlenmiş ya da kurgulanmış bir yapının toplanan verilerle ne derece doğrulandığını incelemeyi amaçlar. Açıklayıcı faktör analizinde belirli bir ön beklenti ya da denence olmaksızın faktör yükleri (ağırlıkları) temelinde verinin faktör yapısı belirlenirken, DFA ise belirli değişkenlerin bir kuram temelinde önceden belirlenmiş faktörler üzerinde ağırlıklı olarak yer alacağı şeklindeki bir öngörünün sinanmasina dayanır.

DFA'da çeşitli uyum indeksi sonuçlarına göre modelin teori ile uyumlu olup olmadığı kararı verilir. Bu uyum indeksleri $\chi 2, \chi 2 / \mathrm{sd}$, GFI, AGFI, RMSEA, RMR, SRMR gibi isimler alır. Uyum indeksleri çok çeşitlidir fakat bu uyum indekslerinden hangilerinin standart kabul edileceği hakkında tam bir uzlaşı olmadığ bildirilmektedir. $\mathrm{Bu}$ çalışmada yapılan DFA için Ki kare uyum testi (Chi-Square Goodness), GFI (Goodness of Fit Index), RMSEA (Root Mean Square Error of Approximation), CFI (Comparative Fit 
Index), NFI (Normed Fit Index), RFI (Relative Fit Index), IFI (Incremental Fit Index) ve AGFI (Adjusted Goodness of Fit
Index) uyum indeksleri incelenmiştir. İncelenen uyum indeksleri ve normal değerleri Tablo 5'te görülmektedir. ${ }^{18-20}$

Tablo 4. Ölçeğin faktör yapısı, öz değerleri ve açıkladıkları varyans değerleri

\begin{tabular}{|c|c|c|}
\hline $\begin{array}{l}\text { Faktör } \\
\text { Grupları }\end{array}$ & Ölçek Maddeleri & $\begin{array}{l}\text { Faktör } \\
\text { Ağırlığı }\end{array}$ \\
\hline \multirow{12}{*}{ Faktör 1} & $\begin{array}{l}\text { 1. Sıcak basması yaşadığım zaman, etrafımdaki insanlar bana bakıyormuş } \\
\text { gibi geliyor }\end{array}$ & .528 \\
\hline & 7. Sicak basması yaşadığım zaman utanıyorum & .773 \\
\hline & 8. Sıcak basması yaşadığım zaman, nasıl göründüğüm konusunda endişeleniyorum & .679 \\
\hline & 9. Sicak basmaları, kendimi itici hissetmeme neden oluyor. & .636 \\
\hline & $\begin{array}{l}\text { 10. Sicak basması yaşadığım zaman, diğer insanlar benim beceriksiz olduğumu } \\
\text { düşüneceklermiş gibi hissediyorum }\end{array}$ & .692 \\
\hline & $\begin{array}{l}\text { 13. Sıcak basması yaşadığım zaman, sanki insanlar benim bir sıkıntım olduğunu } \\
\text { düşüneceklermiş gibi geliyor }\end{array}$ & .634 \\
\hline & 14. Sıcak basması yaşadığımda yapılacak en iyi şey, sosyal ortamlardan uzak durmaktır & .448 \\
\hline & $\begin{array}{l}\text { 16. Diğer insanların sıcak basmalarıyla benden daha iyi baş edebildiklerini } \\
\text { düşünüyorum }\end{array}$ & .522 \\
\hline & $\begin{array}{l}\text { 17. Sıcak basması yaşadığım zaman, başkalarının gözünde aptal gibi göründüğümü } \\
\text { düşünüyorum }\end{array}$ & .617 \\
\hline & 20. Sıcak basması yaşadığımda, kendimi işe yaramaz hissediyorum & .596 \\
\hline & $\begin{array}{l}\text { 21. Sıcak basmaları, diğer insanların hakkımda ne düşündüğüne daha çok önem } \\
\text { vermeme neden oluyor }\end{array}$ & .533 \\
\hline & 23. Sıcak basması yaşadığım zaman, dikkatleri üzerime çektiğimi hissediyorum & .565 \\
\hline \multirow{7}{*}{ Faktör 2} & 3. Gece terlemesi yaşadığım zaman, uykuma geri dönemiyorum & .505 \\
\hline & $\begin{array}{l}\text { 6. İnsanların yanında sıcak basması yaşadığım zaman huzursuz } \\
\text { oluyorum }\end{array}$ & 482 \\
\hline & 12. Sıcak basmalarım nedeniyle kendimi boğulacakmıs gibi hissediyorum & .615 \\
\hline & 19.Sıcak basmaları nedeniyle kendimi kırgın (gücenmiş) hissediyorum. & .456 \\
\hline & 24. Acaba bir sonraki sıcak basması ne zaman olacak diye endişeleniyorum & .621 \\
\hline & 26. Sıcak basması yaşadığım zaman kendimi huzursuz hissediyorum & .697 \\
\hline & 27. Sıcak basması yaşadığımda, bunlar ne zaman sona erecek diye düşünüyorum & .721 \\
\hline \multirow{8}{*}{ Faktör 3} & 2. Sıcak basmalarının verdiği fiziksel rahatsızlık ile başa çıkabilirim & .634 \\
\hline & $\begin{array}{l}\text { 4. Gece terlemesi nedeni ile uykum bölünse de ertesi gün normal hayatıma } \\
\text { devam edebilirim }\end{array}$ & .735 \\
\hline & 5. Sıcak basmalarının yaşamımı olumsuz etkilemesine izin vermem & .743 \\
\hline & $\begin{array}{l}\text { 11. Sıcak basması yaşadığım zaman, diğer insanların bu konuda ne düşündüğünü } \\
\text { umursamam }\end{array}$ & .403 \\
\hline & 15. Sıcak basması yaşadığım zaman, bunu görmezden gelebilirim & .518 \\
\hline & 18. Sıcak basmalarımla etkili bir şekilde baş edebilirim & .707 \\
\hline & 22. Gece terlemesi yaşadığım zaman, ertesi gün işlerimi yapmak daha zor oluyor & .475 \\
\hline & 25. Gece terlemeleri, genel sağlığımı etkilemiyor & .558 \\
\hline & $\begin{array}{c}\text { Faktörlerin Açıkladığı Varyansın } \\
\text { Yüzdesi }\end{array}$ & \\
\hline Faktör 1 & 30.76 & \\
\hline Faktör 2 & 8.84 & \\
\hline Faktör 3 & 6.41 & \\
\hline
\end{tabular}

Yapılan DFA' da ölçeğin Türkçe formunun üç faktörlü modelinin uyum indeksleri incelenmiştir. Birinci Düzey
DFA'ya ilişkin veriler Şekil 1'de görüldüğü gibidir. 
Şekil 1 incelendiğinde, 27 madde ve üç alt faktörden oluşan ölçeğin uyum indeksleri- nin anlamlı olduğu görülmektedir $\left(X^{2}=674.47, \mathrm{sd}=321, \mathrm{p}=.00, X^{2} / \mathrm{sd}=2,10\right)$.

Tablo 5. DFA'da kullanılan uyum iyiliği indeksleri ve normal değerleri

\begin{tabular}{lcc}
\hline İndeks & Normal Değer & Kabul Edilebilir Dĕger \\
\hline$\chi 2$ "p" Değeri & $\mathrm{p}>0.05$ & - \\
\hline$\chi 2 /$ sd & $\leq 2$ & $\leq 5$ \\
\hline RMSEA & $<0.05$ & $<0.08$ \\
\hline NFI, CFI, RFI, & $\geq 0.95$ & $\geq 0.90$ \\
IFI, GFI & $\geq 0.95$ & $\geq 0.90$ \\
\hline AGFI &
\end{tabular}

Uyum indeksi değerleri ise RMSEA=.067, $\mathrm{RMR}=.033, \mathrm{NFI}=.90, \mathrm{CFI}=.93, \mathrm{IFI}=.95$, $\mathrm{RFI}=.90, \quad \mathrm{AGFI}=.85, \quad \mathrm{GFI}=.88$ olarak bulunmuştur. Birinci düzey DFA analizinde 7 ile 8,1 ile 13, 10 ile 17,8 ile 20 ve 10 ile 20 maddeleri arasinda

Şekil 1. Sicak Basması İnanç Ölçeği İle İlgili Birinci Düzey DFA Sonuçları modifikasyon önerileri doğrultusunda modifikasyon yapılmıştır. Modelin bu modifikasyonlardan sonra iyi uyum verdiği görülmüştür. Modelin son haline ilişkin bulgular Şekil 2'de verilmiştir.

Şekil 2. Sicak Basması İnanç Ölçeği İle İlgili Birinci Düzey Modifikasyon Sonras1 DFA Sonuçları

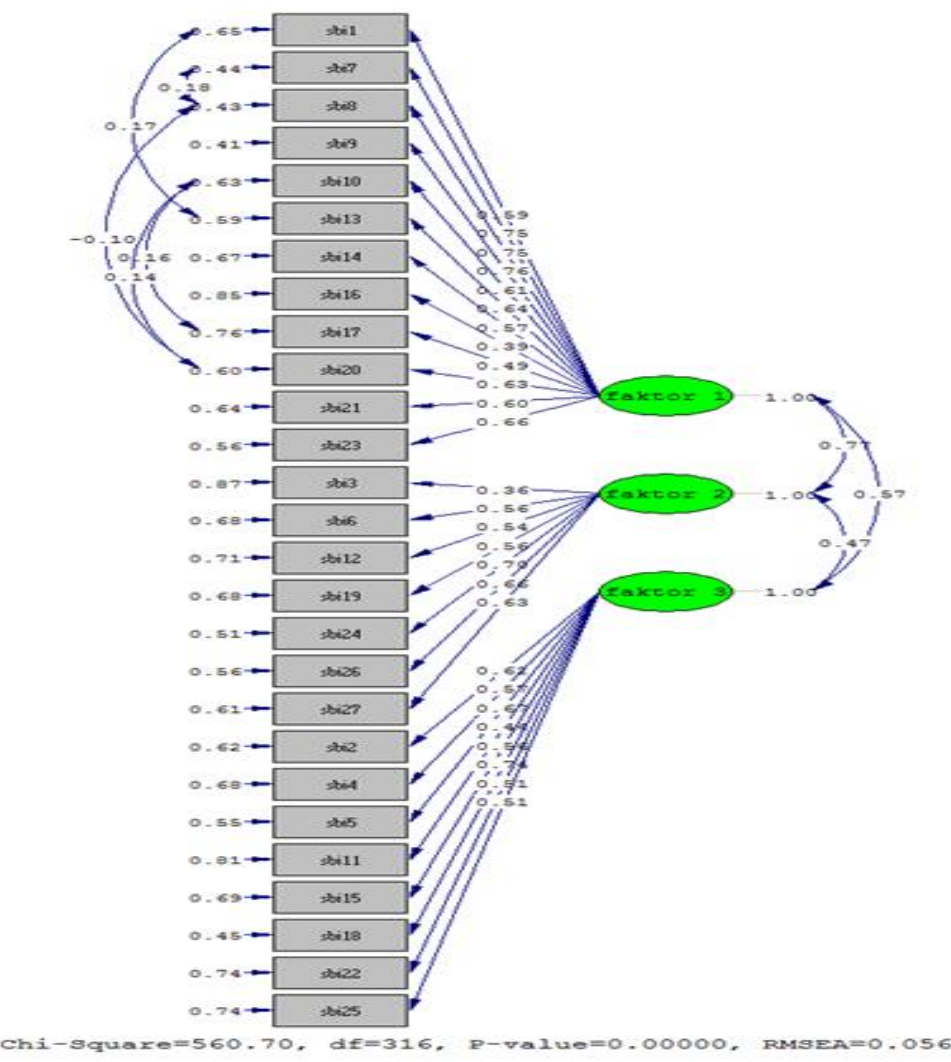


Şekil 2 incelendiğinde, 27 madde ve üç alt faktörden oluşan ölçeğin uyum indekslerinin modifikasyon sonrasında anlamlı olduğu görülmüştür $\left(X^{2}=560,70\right.$, $\left.\mathrm{sd}=316, \mathrm{p}=.00, X^{2} / \mathrm{sd}=1,77\right)$. Uyum indeksi değerleri ise $\mathrm{RMSEA}=.056, \mathrm{RMR}=.027$, NFI $=.92, \quad$ CFI $=.96, \quad \mathrm{IFI}=.97, \quad \mathrm{RFI}=.92$, AGFI $=87$, GFI $=.90$ olarak bulunmuştur. Standart çözümlerden sonra faktörler ve maddeler arasındaki $t$ değerlerine bakılmıştır. Jöreskog ve Sörbom t değerleri ile ilgili kırmızı ok bulunmamasının tüm maddelerin 0.05 düzeyinde anlamlı olduğunu ifade etmektedir. ${ }^{21}$ Analizlerin sonucunda $t$ değerlerine göre tüm maddelerin 0.05 düzeyinde anlamlı olduğu söylenebilir.

\section{Sonuç}

Orijinalinde 3 faktörlü yapı gösteren Sicak Basması İnanç Ölçeği, Türk toplumunda yapılan geçerlik ve güvenirlik çalışmasında benzer şekilde 3 faktörlü yap1 göstermiş ancak ölçekteki 1, 4, 7, 8, 9, 10, 12, 13, 14, 17, 19, 20, 21, 22, 23, 24, 25, 26, 27. maddeler orjinal ölçekte temsil ettikleri alt boyutlar içinde yer alırken, orjinal ölçekte faktöre 1'e ait olan 6. madde faktör 2

\section{Kaynaklar}

1. Hotun Şahin N, Coşkun A. The menopausal age, related factors and climacteric, complaints in Turkish women. Revista Referenc'a 2007; 4: 91-99.

2. Ergöl Ş, Eroğlu K. Klimakterik dönemdeki kadınların sağlık bakımlarına ilişkin uygulama ve tutumları. Sağlık ve Toplum Dergisi 2001; 11: 49-57.

3. Işık $G$, Vural $G$. Menopoz polikliniğine başvuran ve hormon replasman tedavisi başlanan kadınların tedavilerine ilişkin bilgi ve görüşleri. Hemşirelik Araştırma Dergisi 2001; 1: 39-48.

4. Tortumluoğlu G, Pasinlioğlu T. Klimakterik yakınması olan kadınların alternatif tedavi yöntemlerini uygulama durumlar1. Atatürk Üniversitesi içinde, 11.madde faktör 3 içinde yer almıştır. Faktör 2'ye ait olan 2, 5, 15 ve 18. maddeler faktör 3 içinde, 16. madde faktör 1 içinde yer almıştır. Faktör 3' e ait olan 3.madde ise faktör 2 içinde yer almıştır. İlgili maddelerin faktörler arası yer değiştirmesi sonucu orijinal ölçeğin "sosyal bağlamda kendisi hakkındaki inançlar (Sosyal Algl)" alt boyutu ismi aynı kalmış orijinal ölçeğin "sıcak basması ile başa çıkma konusundaki inançları" alt boyutu ile "gece terlemesi ile başa çıkma konusundaki inançları" alt boyutu birleşerek "sicak basmasl ve gece terlemesi ile başa çıkma konusundaki inançları (Başetme Algisl)" adını almış ve ölçeğin üçüncü alt boyutunu oluşturmuştur. İkinci alt boyuta ise ilgili faktörde yer alan maddelerin anlamlarına uygun olarak "psikolojik bağlamda kendisi hakkındaki inançlarl (Psikolojik algl)" adı verilmiştir

Sonuç olarak SBİÖ'nin oldukça yüksek geçerlik ve güvenirlik göstergelerine sahip bir ölçme aracı olduğu saptanmıştır. Klimakterik dönemdeki kadınların sıcak basması ve gece terlemesine ilişkin düşüncelerini ve inançlarını ölçmek amacıyla kullanılabilir.

Hemşirelik Yüksekokulu Dergisi 2003; 6: 64-75.

5. Görgel E, Çakıroğlu FP. Menopoz Döneminde Kadın, birinci basım, Ankara, Ankara Üniversitesi Basım Evi, 2007.

6. Kişnişci HA, Gökşin E, Durukan T, Üstay K, Ayhan A, Gürgan T ve ark. Temel Kadın Hastalıkları ve Doğum Bilgisi, birinci basım, Ankara, Güneş Kitabevi, 1996.

7. Hunter MS, Liao KLM. A psychological analysis of menopausal hot flushes. Br J Clin Psychol 1995; 34: 589-599.

8. Şeker H, Gençdoğan B. Psikolojide ve Eğitimde Ölçme Aracı Geliştirme, Ankara, Nobel Yayınevi, 2006.

9. Gözüm S, Aksayan S. Kültürleraras1 ölçek uyarlaması için rehber I. ölçek 
uyarlama aşamaları ve dil aşamaları. Hemşirelikte Araştırma Geliştirme Derg 2002; 4: 9-20.

10. Yurdakul M, Eker A, Kaya D. Menopozal dönemdeki kadınların yaşam kalitesinin değerlendirilmesi. Furat Üniversitesi Sağ Bil Derg 2007; 21: 187-193.

11. Rendall MJ, Simonds LM, Hunter MS. The Hot Flush Beliefs Scale: A tool for assessing thoughts and beliefs associated with the experience of menopausal hot flushes and night sweats. Maturitas 2008; 60: 158-169.

12. Akgül A. Tibbi Araştırmalarda İstatistiksel Analiz Teknikleri- SPSS Uygulamaları, Üçüncü baskı, Ankara, Ocak Yayınları, 2005.

13. Burns N, Grove SK. The Practice of Nursing Research. Conduct, Critique and Utilization. fifth ed., Philadelphia, WB Saunders, 2004.

14. Harrington D. Confirmatory Factor Analysis. Newyork, Oxford University Press, 2009.
15. Ercan İ, Kan İ. Ölçeklerde güvenirlik ve geçerlik. Uludağ Üniversitesi Tip Fakültesi Dergisi 2004; 30: 211-216.

16. Büyüköztürk Ş. Sosyal Bilimler için Veri Analizi El Kitabı. Ankara, Pegem Akademi Yayıncılık, 2002.

17. Sümer N. Yapısal eşitlik modelleri: Temel kavramlar ve örnek uygulama. Türk Psikoloji Yazıları 2000; 3: 49-73.

18. Şimşek ÖF. Yapısal Eşitlik Modellemesine Giriş; Temel İlkeler ve LISREL Uygulamaları. Ankara, Ekinoks Yayınları, 2007.

19. Meydan $\mathrm{CH}$, Şeşen H. Yapısal Eşitlik Modellemesi AMOS Uygulamas1. Ankara, Detay Yayıncılık, 2011.

20. Bayram N. Yapısal Eşitlik Modellemesine Giriş: AMOS Uygulamaları. Bursa, Ezgi Kitabevi, 2010.

21. Jöreskog KG, Sorbom D. LISREL 8.54 reference guide. Lincolnwood, IL: Scientific Software International, 1996. 